\title{
Insight into the Links among External Business Environments, Corporate Governance and Organisational Performance
}

\author{
Quang Linh Huynh (Corresponding author) \\ School of Economics \& Law, Tra Vinh University, Tra Vinh, Vietnam \\ E-mail: huynhquanglinh@tvu.edu.vn
}

Received: Feb. 12, 2018 Accepted: March 19, $2018 \quad$ Published: June 1, 2018

doi:10.5296/ajfa.v10i1.12655 URL: https://doi.org/10.5296/ajfa.v10i1.12655

\begin{abstract}
The existing literature has acknowledged the complicated links among external business environments, corporate governance and organisational performance. However, a large void exists in the extant research models of corporate governance, because none have discussed and empirically examined the intervenient effect of the corporate governance mechanism on the external business environments and organisational performance. A thorough review of the literature on corporate governance, external business environments and organisational performance comes to the proposed hypotheses. The indirect effect of external business environments on organisational performance via corporate governance is statistically tested. The research provides empirical evidence that organisational performance is the consequence of both corporate governance and external business environments that is, in turn, the causality of corporate governance. More importantly, it offers insight into the mediating effect of corporate governance in transforming the uncertainty of external business environments into organisational performance. The findings suggest that firms facing uncertainty in external business environments should adopt suitable corporate governance to achieve the best organisational performance.
\end{abstract}

Keywords: Corporate governance, Organisational performance, External business environments, Quantitative method, Mediation effect

JEL code: C51, G34, L25 


\section{Introduction}

The fall of WorldCom (in 2002) and Enron (in 2001) in the United States has drawn scholarly attention to corporate governance research (Altunoglu 2012). These scandals have also triggered the adoption of good corporate governance within firms, especially those that are publicly listed (James and Joseph 2015). Research on corporate governance has been traditionally grounded in agency theory, which explicates the interplays of principals (owners) with agents (managers) and agent-principal problems resulting from conflicts between the owners and managers in term of interests (Eisenhardt 1989). The agency theory emphasises the role of corporate governance as an instrument to lessen agency conflicts between the shareholders and the executives running their firms. Hence, it can enhance organisational competitive advantages and gain sustainable improved performance (Fooladi and Chaleshtori 2011).

Several corporate governance academics have revealed that agency theory has become governing in the code of corporate governance practices due to its contribution to management knowledge and practice and policy implementation (Lan and Heracleous 2010; Shleifer and Vishny 1997). Following Lan and Heracleous (2010), almost all experiential research has attempted to comprehend the mechanism of corporate governance by employing the agency theory to examine relationships between the mechanism of corporate governance and organisational effectiveness. Nevertheless, Aguilera et al. (2008) argues that agency theory has been censured for its viewpoint of the closed system of organisation, establishing a general set of links between corporate governance mechanisms and organisational performance, without paying much attention to the organisation's contextual conditions. This will affect the agency theory's ability to correctly explain suitable corporate governance mechanisms across different external business environments (Aguilera et al. 2008; Aguilera and Jackson 2003).

Conversely, the contingency theory supports the approach of an open organisation and declines the perspective of the general best mechanisms advocated by the agency theory (Donaldson 2001). The core of the contingency theory advocates that different corporate governance practices can be more or less efficient in diverse business environments (Aguilera et al. 2008; Scott 2003), conditional upon numerous contextual factors (e.g., external business environments (Otley 1980)). Scholars have drawn on the agency theory to emphasise the importance of a sound corporate governance mechanism in enhancing organisational performance (Aguilera et al. 2008; Aguilera and Jackson 2003). Other academics have relied on the contingency theory to recommend that organisational effectiveness stems from the matching between organisational characteristics (e.g. corporate governance practices) and contextual contingencies (e.g. external business environments) facing the organisation (Donaldson 2001; Ezzamel and Hart 1987).

Implied from the contingency theory, the mechanism of corporate governance plays a role as a mediator in transmitting the effect of external business environments into organisational performance (Donaldson 2001; Aguilera et al. 2008; Scott 2003; Ezzamel and Hart 1987). Furthermore, for Margolis and Walsh (2003), it is necessary to develop research models 
which integrate contextual conditions and organisational variables, and test mediating mechanisms often ignored, as well as set up the causal relationships among the environmental contexts, organisational variables and organisational performance. Therefore, this research takes into account the potential for a mediating influence to more broadly explore the contribution of corporate governance and external business environments to organisational effectiveness. For this objective, this article makes an imperative contribution to the hypothetical advancement of the external business environments - corporate governance firm performance linkage suggested by Elghrabawy (2012). This study joins agency problems with contingencies and an institutional perspective to conjecture a hypothetical model of the dynamics of corporate governance and organisational performance (Figure 1) and investigate the extent to which the influence of external business environments on organisational performance is mediated by corporate governance mechanisms.

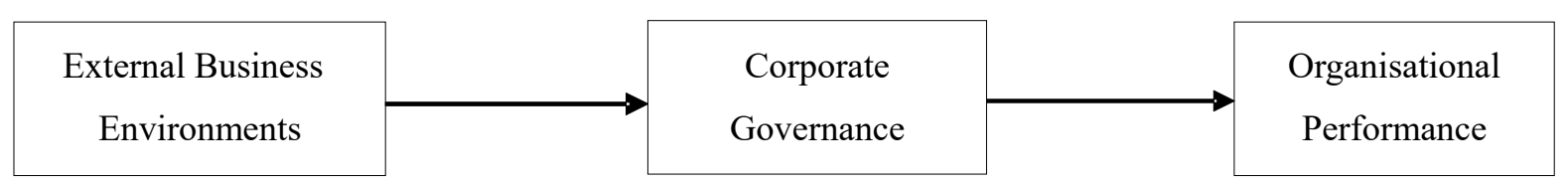

Figure 1. The link among corporate governance, external business environments and organisational performance.

To the best of the researcher's knowledge, this paper is the first to study the mediation of the corporate governance mechanism on the impact of external business environments on organisational performance. The findings are expected to provide researchers and executives with new insight into the complex research model of corporate governance. The findings are expected to be helpful to business directors of firms in making better decisions on the application of suitable corporate governance for their external business environments, so as to best improve organisational effectiveness.

\section{Conceptual developments and hypotheses}

All business organisations, which are open systems connected to their external business environments, aim to achieve their best organisational performance by wisely using resources to obtain profits (Scott 2001). Organisational performance is the actual outcome of a firm that is evaluated in terms of non-financial and financial indicators (Hudson et al. 2001; Droge et al. 2003). Anchored in agency theory, this article establishes the role of the corporate governance mechanism in boosting firm performance, based on Aguilera et al. (2008) and Aguilera and Jackson (2003). It is based on the contingency theory to recommend that the best organisational performance originates from the fitting between the corporate governance mechanism and its external business environments (Donaldson 2001). The contingency theory mentions firm performance, when discussing the effects of externally environmental variables on organisational variables. However, this theory cannot clearly explain the interdependence between external business environments and organisational performance (Volberda et al. 2012). On the contrary, institutional theory focusing on a firm's relationship with its external business environments asserts that the organisational effectiveness, in part, depends on the external business environments (Scott 2001; Zucker 1987). 
Grounded in agency theory, Bhagat and Bolton (2008) discover a positive correlation between corporate governance and organisational performance. Research on the role of managerial boards highlights that an individual taking charge of the chief executive officer, together with the chairman, often pursues their own benefit at the expense of other stakeholders. However, if the chief executive officers hold a large number of their firm's stocks, then their benefits are in agreement with other shareholders (White and Ingrassia 1992). Therefore, they would act in $n$ ways that benefit the firm. Furthermore, organisations with managerial boards composed of independent directors in a majority will counteract agency problems, because these managerial boards could oversee the self-interested actions taken by executives, which alleviates the agency problems, and leads to a more enhanced organisational performance (Kaymak and Bektas 2008; Nicholson and Kiel 2007).

Independent executives are generally recruited for their excellent qualifications, knowledge and experience. In this way, they may make more efficient business decisions. At the same standpoint, Bebenroth and Donghao (2007) underline the important supervisory role of the independent executives, which is to reduce the agency costs enhancing the organisational performance. This means that a firm can undergo poorer performance, if its managerial boards cannot supervise the underperforming directors. In addition, several previous studies suggest that a good mechanism of corporate governance will promote the creation of good organisational performance (Ljubojevic et al. 2013; Zabri et al. 2016; Bualla et al. 2017).

Drawing on the contingency theory, Soltani (2005) examines the factors affecting corporate governance and identifies a positive relationship between a firm's existing corporate governance and its external business environments. Duncan (1972) relates external business environments to suppliers, customers or clients, competitors, technologies and social-political issues. Heinrich et al. (2007) proposes four elements of external business environments: 1. contingent factors related to being under pressure from outside minority shareholders, 2 . pressure from majority shareholders, 3. pressure from state legal regulations, and 4. pressure from globalization. Heinrich et al. (2007) then emphasise that these elements likely drive corporate governance.

The importance of external business environments in structuring corporate governance is confirmed in Altunoglu (2012), where the uncertainty of external business environments will force executives to build appropriate corporate governance mechanisms to deal with the changing situation for survival. For Aguilera et al. (2008) and Afolabi (2015), external business environments are imperative to a firm's corporate governance mechanism in which high environmental uncertainty requires managers to build a sound corporate governance mechanism.

Volberda et al. (2012) adhere to the institutional perspective to explore the dependence of organisational behaviour on organisational context. These academics highlight that numerous facets of firms are driven by the desire to attain the fit with their external business environments. Institutional fit improves organisational performance through diverse managerial mechanisms (e.g., corporate governance (Levitt and March 1988)). Other research has discussed and examined the effect of external business environments on organisational 
performance. Choe (2003) suggests external business environments as a causation of organisational performance. Additionally, Adeoye and Elegunde (2012) explore the causal links between external business environments and organisational performance, verifying that external business environments impose a significant effect on organisational performance.

Given the interaction between organisations and their external business environments, the business organisations try to understand, react and impact external business environment changes to obtain the best possible organisational performance (Adeoye and Elegunde 2012). Similarly, drawing on Mia and Clarke (1999), organisational performance is expected to be improved in a highly competitive business environment. Furthermore, when external business environments are progressively uncertain, executives often pay more attention to their business activities, which would result in improved organisational performance (Ajibolade et al. 2010). Moreover, the specific external business environments facing an organisation could make an essential contribution to the organisational competitive capability and organisational performance (Vo 2015; Ibrahim and Primiana 2015; Pratistha 2016; Kuznetsova et al. 2017). The interdependence between external business environments and organisational performance is also examined by Abdallah and Persson (2014), who argue that an organisation facing high environmental uncertainty needs to fit itself to the environmental change to improve its organisational performance.

For the role of corporate governance, Volberda et al. (2012) incorporate institutional and contingency perspectives to propose that an organisation needs to match its corporate governance with external business environments to achieve superior performance. This means that an appropriate mechanism of corporate governance depends on external business environments to attempt to obtain greater organisational performance. The previously discussed reasoning leads to a mediating mechanism in which external business environments will increase their organisational performance through a good mechanism of corporate governance.

Consequently, four hypotheses can be developed:

(1) Hypothesis 1: Higher uncertainty of external business environments can lead to better organisational performance;

(2) Hypothesis 2: Good corporate governance can bring about superior organisational performance;

(3) Hypothesis 3: Higher uncertainty of external business environments is positively related to better corporate governance; and

(4) Hypothesis 4: Corporate governance can mediate the causal link from external business environments to organisational performance

\section{Research methodology}

Data was collected from executives involved in corporate governance (one executive for each selected firm). Each executive was asked to fill out a survey. The research population was composed of all 1142 public firms listed on the Vietnamese Stock Exchanges in the first 
quarter of 2017. Vietnam was selected, because it is the most rapidly growing and emerging market in Asia and little attention to Vietnamese corporate governance has been paid (Ahmad et al. 2003; Vo 2015). A simple random sampling was employed to gather the data.

The 400 executives of the randomly selected firms were interviewed in person with the questionnaires based on the following constructs (Hair et al. 2009). Surveys without essential adequate information were deleted from the database. Overall, there were 349 usable responses. External business environments (EBE) were judged on five elements: 1) Governmental policies-EBE1, 2) Economy-EBE2, 3) Resources and services used by the firm-EBE3, 4) Product market and demand-EBE4, and 5) Competition-EBE5 (Miller 1993; Brouthers et al. 2002). These elements were measured on a five level scale: always forecasted, easily forecasted, a little hard to be forecasted, quite hard to be forecasted and very hard to be forecasted (Chenhall and Morris 1986).

Organisational Performance (OPE) is assessed on five items: 1) Innovativeness-OPE1, 2) Quality in products or services-OPE2, 3) Customer satisfaction-OPE3 (nonfinancial), 4) Return on assets-OPE4, and 5) Return on equity-OPE5 (financial) (Hudson et al. 2001; Droge et al. 2003). A comparison of the industry-average for the items with a five-point scale from no growth, a little growth, average growth, fast growth and very fast growth, during the last three years, was made. Corporate Governance (CGO) refers to the proportion of independent directors-CGO1, the proportion of independent supervisors-CGO2 and the proportion of the firm's stock owned by the chief executive officer-CGO3 (Bhagat and Bolton 2008).

This research uses path analyses to explore the causal relationships among external business environments, corporate governance and organisational performance. Path analysis is an expansion of multiple regressions applied to simultaneously examine a set of causal relationships. It is also employed to inspect the mediation of one variable on the causal links among the other variables (Hair et al. 2009). This research applies path analyses, because the method of maximum likelihood used in the path analyses takes into consideration the potential correlations amongst disturbances, which is robust to abnormality and misspecification (Olsson et al. 2000). It then employs the mediating analytic technique to test the statistical significance for the intermediary effect of corporate governance by using the methods advocated by Baron and Kenny (1986) and Spencer (2011). The indirect influence by mediation is tested with a t-test, in which the t-statistic is calculated as a ratio of the indirect estimate to its standard error.

\section{Empirical findings}

After the data was collected and cleaned, a confirmatory factor analysis was conducted to test the factor structure of the set of measured variables. This analysis tests how well the observed variables represent their underlying latent factors or how well the data fits the theorised measurement model. The statistical indices used to assess the goodness of fit of the theorised measurement model are presented in Table 1.

The figures in Table 1 convey the information on the goodness of fit for the theoretical measurement model. The X2/df value of 1.964 is smaller than 2, indicating an acceptable fit 
of the theoretical model with the analysed data (Byrne 1991). RMSEA is the index of the Root Mean Square Error of Approximation, obtaining the value of 0.053, which is lower than the recommended threshold of 0.06 (Hu and Bentler 1999). The IFI (Incremental fit index) was 0.966, the TLI (Tucker-Lewis coefficient) was 0.956, the CFI (Comparative fit index) was 0.965 and the GFI (Goodness of fit index) was 0.949. All of these values were larger than 0.9, the smallest cutoff value suggested by Hair et al. (2009). On the whole, these indicators demonstrate a good fit of the theoretical model to the sample data.

Table 1. Goodness of fit indices

\begin{tabular}{ccccccc}
\hline Fit Index & $\mathrm{X}^{2} / \mathrm{df}$ & RMSEA & IFI & TLI & CFI & GFI \\
\hline Value & 1.964 & 0.053 & 0.966 & 0.956 & 0.965 & 0.949 \\
Results & Good & Good & Good & Good & Good & Good \\
\hline
\end{tabular}

The statistics for the construct validity and reliability of the theoretical model are illustrated in Tables 2 and 3, stipulated by Hair et al. (2009). The factor loading is simply the correlation between each measured variable and its latent construct. Hence, it represents the relationship of the latent construct with each measured variable. The average variance extracted (AVE) is a summary measure of convergence among a set of measured variables representing a latent construct and computed on the average percent of variance in the latent construct explained among the measured variables. The construct reliability (CR) is a measure of the overall reliability of a set of heterogeneous, but similar, measured variables. The CR for each factor could be achieved by the sum of the squared standardised factor loadings divided by the total of that sum and the sum of the error variances for the measured variables of the factor.

Table 2. Measurement model results

\begin{tabular}{ccc}
\hline Observed variables & Constructs & Factor Loading \\
\hline EBE1 & & $0.762 * * *$ \\
EBE2 & External Business environment (EBE) & $0.715^{* * *}$ \\
EBE3 & $0.685 * * *$ \\
EBE4 & $0.684 * * *$ \\
EBE5 & & $0.708 * * *$ \\
\hline CGO1 & Corporate governance (CGO) & $0.702 * * *$ \\
CGO2 & & $0.679 * * *$ \\
CGO3 & & $0.772 * * *$ \\
OPE1 & & $0.765 * * *$ \\
OPE2 & & $0.645 * * *$ \\
OPE3 & & $0.753 * * *$ \\
OPE4 & & $0.704 * * *$ \\
OPE5 & Organizational performance (OPE) & $0.688^{* * *}$ \\
\hline
\end{tabular}

***Significance at the $1 \%$ level

The factor loadings of the three main constructs in Table 2 , ranging from 0.645 to 0.772 , are over 0.5 , the acceptable cutoff value proposed by Hair et al. (2009). The relationship from the 
latent construct "OPE" to item "OPE2" is the lowest, at 0.645 . The correlation between the latent factor "CGO" and indicator "CGO3" was 0.772 , the highest value. All factor loadings achieve statistical significance at the $1 \%$ level. The findings are acceptable, because the high correlations between the latent factor and its indicators demonstrate high reliability.

Table 3 illustrates the AVEs, varying from 0.506 to 0.517 , where numbers greater than 0.5 are acceptable. In addition, all three CRs obtain values greater than the acceptable threshold of 0.7 (ranging from 0.762 to 0.838 ) (see Table 3). As such, the high estimates illustrate the high reliability of the constructs. Consequently, it can be concluded that a set of measured variables reflect their theorised latent construct. The theoretical measurement model achieves adequate convergent validity. Table 3 also offers support for discriminant validity. That is, all the AVEs are bigger than their corresponding SICs. This result indicates that the observed items have more in common with their factors than they do with the other factors.

To test whether the problem of multicollinearity occurs within the sample data, Kennedy (1992) suggests that an acceptable level of inter-construct correlation (IC) should not be larger than the 0.8 cutoff. The ICs in Table 3 range from 0.407 to 0.707 . Hence, multicollinearity does not exist for the dataset. In addition, the bootstrapping technique, a non-parametric method relying on random sampling with replacement for 1,000 times, is used to assess the accuracy of the measurement model (Efron 1988). This research estimates all loadings and related bootstrapping t-critical ratios through 1000 bootstrapping runs. All the indices in the measurement model obtain the values of the bootstrapping t-critical as above 1.96 (un-tabulated), the lowest value suggested by Hulland (1999). This demonstrates a highly adequate reliability of the statistical estimates in the measurement model. These results collectively offer adequate validity of the measurement model with the analysed data.

Table 3. Matrix of IC, AVE, CR and SIC

\begin{tabular}{cccc}
\hline & EBE & CGO & OPE \\
\hline EBE & & 0.174 & 0.166 \\
CGO & 0.417 & & 0.499 \\
OPE & 0.407 & 0.707 & \\
\hline AVE & 0.506 & 0.517 & 0.510 \\
CR & 0.836 & 0.762 & 0.838 \\
\hline
\end{tabular}

Values below the diagonal are CRs, AVEs and ICs (inter-construct correlations)

Values above the diagonal are SICs (squared inter-construct correlations)

In regard to the causal links in the research model, the results are outlined in Figures 1 and 2. The findings of the path analyses offer statistically empirical support for Hypotheses 1 through 3. Both Figures 1 and 2 indicate that the uncertainty of the external business environments positively influences the organisational performance, with $\beta=0.33$ (Figure 2) and $\beta=0.15$ (Figure 3), at a significance level of $1 \%$. Furthermore, Figure 3 demonstrates that the uncertainty of the external business environments and corporate governance are both positively related to the organisational performance, in that corporate governance $(\beta=0.54)$ is stronger than the uncertainty of external business environments $(\beta=0.15)$ in improving the organisational performance. 


\section{$\mathrm{EBE}$

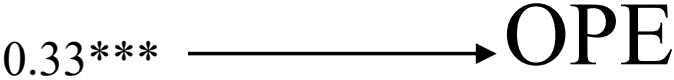

$$
\left(\mathrm{R}^{2}=0.12 * * *\right)
$$

Figure 2. Path diagram denoting the causal relationship

(***Significance at the $1 \%$ level)

The models achieve an adequate goodness of fit at a significance level of $1 \%$. The uncertainty of the external business environments alone statistically explains $12 \%$ of the variation in the organisational performance at a statistical significance level of $1 \%$ (Figure 2). The uncertainty of the external business environments and the corporate governance explain $38 \%$ of the variation in the organisational performance (Figure 3). These findings empirically support Hypotheses 1 and 2. In addition, the statistics in Figure 3 empirically support the causal link from the uncertainty of external business environments to corporate governance with an affecting coefficient of 0.33 at a statistical significance level of $1 \%$. The uncertainty of external business environments alone accounts for $11 \%$ of the variance in corporate governance, supporting Hypothesis 1.

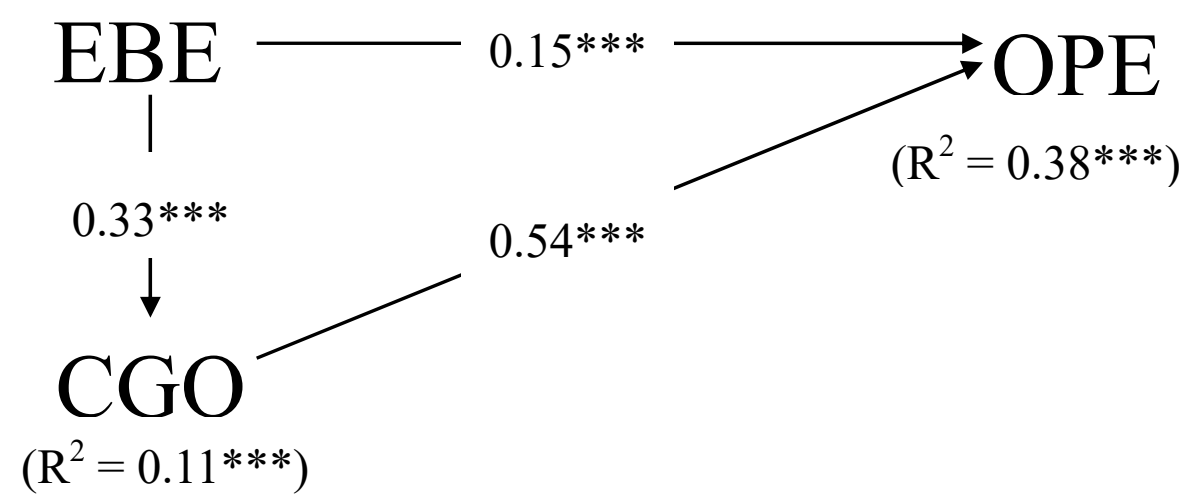

Figure 3. Path diagram denoting the theorized causal models

(***Significance at the $1 \%$ level)

Overall, the path diagram in Figure 2 shows that the uncertainty of the external business environments alone affects organisational performance at a statistical significance of $1 \%$. The addition of corporate governance into the research model results in a decrease in the affecting magnitude of external business environments uncertainty on organisational performance from 0.33 (in Figure 2) to 0.15 (in Figure 3). The positive relationships of corporate governance with external business environments, as well as organisational performance, are statistically significant at $1 \%$. In addition, the total effect of the external business environments on organisational performance is 0.33 , while the direct effect is 0.15 and the indirect effect through corporate governance is $0.18(=0.33 * 0.54)$.

These findings suggest the mediating role of corporate governance in the research model. The 
results of the mediation test presented in Table 4 offers empirical evidence of the indirect effect of external business environments to organisational performance through corporate governance. The causal link from external business environments to organisational performance is statistically mediated by corporate governance at the significance level of $1 \%$, with t-statistics (indirect) of 5.755, in support of Hypothesis 4. It can be therefore concluded that when corporate governance is included in the research model, the influence of external business environments uncertainty on organisational performance is partially transmitted through it. As a consequence, the influence will decrease.

Table 4. Results for testing the mediating effect

\begin{tabular}{cccc}
\hline Mediator & Causal effect & $t_{\text {indirect }}$ & $P_{\text {value }}$ \\
\hline CGO & EBE on OPE & 5.755 & 0.000 \\
\hline
\end{tabular}

\section{Discussion and conclusions}

The research findings shed insight on the complicated relationships among external business environments, corporate governance and organisational performance. This study provides statistical support for the argument that the uncertainty of external business environments has a significant influence on organisational performance, revealing that executives facing a high level of uncertainty in their external business environments become more concerned about organisational performance. This is consistent with the findings of Pelham (1999), Nicolaescu (2012) and Ajayi (2016), which state that higher environmental uncertainty makes firms use their limited resources more effectively and efficiently. This may help them gain a competitive advantage over their business rivals.

This study also emphasises the relationships of corporate governance with organisational performance and external business environments. In the context of corporate governance, previous research (Choe 2003; Soltani 2005; Heinrich et al. 2007; Nicholson and Kiel 2007; Bhagat and Bolton 2008; Altunoglu 2012) argues that the uncertainty of external business environments pushes firms to develop better corporate governance, which results in a better system of management and better organisational performance is achieved. In this way, the firms survive and develop in an increasingly competitive external business environment. This research takes this theoretical contention and offers empirical verification that corporate governance is statistically supported as a consequence of external business environments, but as a causal factor of organisational performance. This is consistent with most of the previous findings (e.g., Choe 2003; Bhagat and Bolton 2008; Aguilera et al. 2008; Volberda et al. 2012; Adeoye and Elegunde 2012; Abdallah and Persson 2014; Afolabi 2015; Vo 2015). However, these results contradict the findings of Weir and Laing (2001), that report an unclear connection between corporate governance and organisational performance. This inconsistency could be related to the difference in the empirical context in that one study was performed in the UK, a developed country, and the other in Vietnam, a developing country.

Finally, the current research highlights and focuses on the important role of corporate governance in the research model. The findings offer significant support for the indirect effect of external business environments on organisational performance. This is mediated through corporate governance, which is an important extension of the extant management literature of 
the simply causal relationships among external business environments, corporate governance and organisational performance. This hypothesises a theoretical contention, rather than a direct effect. External business environments indirectly contribute to organisational performance via corporate governance by the mediating mechanism.

This insight reflects the essential role of corporate governance in business activities in which corporate governance should appropriately respond to the uncertainty of external business environments to achieve competitive advantages and gain the best possible organisational performance. More significantly, the corporate governance model in this study has been statistically explored in the context of an emerging economy in Asia (including Vietnam), which has received little attention in terms of corporate governance (Ahmad et al. 2003). Therefore, this finding can be an extension of the existing literature on corporate governance theory to developing Asian countries.

Furthermore, this research provides some implications for business managers and practitioners, shedding light on the important role of corporate governance in improving organisational performance. With that new knowledge, executive officers could decide to fit corporate governance with the uncertainty of the external business environments facing the firms. This would boost sustainable business development and transmit the uncertainty of external business environments into better organisational performance.

\section{Limitations and future directions}

The author acknowledges some limitations of this investigation. First, the data used in the research is based on survey responses offered by a single respondent in each firm. Hence, a bias problem can exist, because different respondents across firms are pooled into a single dataset (Bou-Llusar 2016). Future research should employ multiple-informant research designs to eradicate the potential bias problem. Second, this study was performed in Vietnam, as an emerging business environment in Asia. However, the findings are expected to be applied to other emerging business environments. Business conditions among emerging business environments may be dissimilar ( Tu 2012). Therefore, care must be taken in generalizing these results. Furthermore, there is an inconsistency in the link between corporate governance and organisational performance. Future research should compare the relationship between developed and developing business environments.

\section{Acknowledgements}

The author is deeply thankful to the informants in the selected firms for providing necessary information for this project. The author himself makes all the contributions to the conception and design as well as the acquisition, analysis and interpretation of the data. There is no conflict of interest for this work.

\section{References}

Adeoye A.O., \& Elegunde A.F. (2012). Impact of External Business Environment on Organisational Performance in the Food and Beverage Industry in Nigeria. British Journal of Arts and Social Science, 6(2), 194-201 
Abdallah L., \& Persson M. (2014). The effects of environmental uncertainty conditions on organisational innovativeness and performance of SMEs, Master thesis. Department of Industrial Economics, Blekinge Institute of Technology, Sweden

Afolabi A.A. (2015). The Impact of External Factors on Corporate Governance system of firms: Empirical Evidence from Sub-Saharan Africa Anglophone Countries (SSAA). Global Advanced Research Journal of Management and Business Studies, 4(1), 016-035

Aguilera R.V., Filatotchev I., Gospel H. and Jackson G. (2008). An organisational approach to comparative corporate governance: Costs, contingencies, and complementarities. Organisation Science, 19(3), 475-492. https://doi.org/10.1287/orsc.1070.0322

Aguilera R.V., \& Jackson G. (2003). The cross-national diversity of corporate governance: Dimensions and determinants. Academy of Management Review, 28(3), 447-465

Ahmad A.C., Ishak Z., \& Abd N.A. (2003). Corporate governance, ownership structure and corporate diversification: Evidence from the Malaysian listed companies. Asian Academy of Management Journal, 8(2), 67-89

Ajayi A. (2016). Impact of External Business Environment on Organisational Performance of Small and Medium Scale Enterprises in Osun State, Nigeria. Scholedge International Journal of Business Policy and Governance, 3(10), 155-166

Ajibolade S.O., Arowomole S.S.A., \& Ojikutu R. K. (2010). Management accounting systems, perceived environmental uncertainty and companies' performance in Nigeria. International Journal of Academic Research, 2(1), 195-201

Altunoglu A.E. (2012). Effects of Environmental and Organisational Factors on Corporate Governance Practices. Anadolu University Journal of Social Sciences, 12(3), 51-62

Baron R.M., \& Kenny D.A. (1986). The moderator-mediator variable distinction in social psychological research: Conceptual, strategic, and statistical considerations. Journal of $\begin{array}{llll}\text { Personality and Social } & \text { Psychology, } & \text { 51(6), } & \text { 1173-1182. }\end{array}$ https://doi.org/10.1037/0022-3514.51.6.1173

Bebenroth R., \& Donghao L. (2007). Performance Impact at the Board Level: Corporate Governance in Japan. Asian Business and Management, 6(3), 303-326. https://doi.org/10.1057/palgrave.abm.9200227

Bhagat S., \& Bolton B. (2008). Corporate governance and firm performance. Journal of Corporate Finance, 14(3), 257-273. https://doi.org/10.1016/j.jcorpfin.2008.03.006

Bou-Llusar J.C., Beltran-Martin I., Roca-Puig V., \& Escrig-Tena A. B. (2016). Single- and Multiple-Informant Research Designs to Examine the Human Resource Management-Performance Relationship. British Journal of Management, 27(3), 646-668. https://doi.org/10.1111/1467-8551.12177

Brouthers K.D., Brouthers L.E., \& Werner S. (2002). Industrial sector, perceived environmental uncertainty and entry mode strategy. Journal of Business Research, 55(6), 495-507. https://doi.org/10.1016/S0148-2963(00)00154-5 
Buallay A., Hamdan A., \& Zureigat Q. (2017). Corporate Governance and Firm Performance: Evidence from Saudi Arabia, Australasian Accounting. Business and Finance Journal, 11(1), 78-98

Byrne B.M. (1991). The Maslach Burnout Inventory: validating factorial structure and invariance across intermediates, secondary, and university educators. Multivariate Behavioral Research, 26(4), 583-605. https://doi.org/10.1207/s15327906mbr2604_2

Chenhall R.H., \& Morris D. (1986). The Impact of Structure, Environment and Interdependence on the Perceived Usefulness of Management Accounting Systems. The Accounting Review: American Accounting Association, 61(1), 16-35

Choe J. (2003). The effect of environmental uncertainty and strategic applications of IS on a firm's performance. Information and Management, 40(4), 257-268. https://doi.org/10.1016/S0378-7206(02)00008-3

Donaldson L. (2001). The contingency theory of organisations, London: Sage Publications Ltd, UK. https://doi.org/10.4135/9781452229249

Droge C., Claycomb C., \& Germain R. (2003). Does knowledge mediate the effect of context on performance, Some initial evidence. Decision Sciences, 34(3), 541-568. https://doi.org/10.1111/j.1540-5414.2003.02324.x

Duncan R.B. (1972). Characteristics of Organisational Environments and Perceived Environmental Uncertainty. Administrative Science Quarterly, 17(2), 313-327. https://doi.org/10.2307/2392145

Efron B. (1988). Bootstrap confidence intervals: Good or bad?. Psychological Bulletin, 104(2), 293- 296. https://doi.org/10.1037/0033-2909.104.2.293

Eisenhardt K. (1989). Agency theory: An assessment and review. Academy of Management Review, 14(1), 57-74

Elghrabawy A. (2012). A Contingency Framework of Enterprise Governance in the UK: A Value-Based Management Approach, PhD thesis in Accounting. Brunel Business School, Brunel University, London, UK

Ezzamel M., \& Hart H. (1987). Advanced management accounting: An organisational emphasis. London: Cassell, UK

Fooladi M., \& Chaleshtori G.N (2011). Corporate Governance and Firm Performance. International Proceedings of Economics Development and Research (IPEDR), 10.

Hair J.F., Black W. C., Babin B. J., Anderson R. E., \& Tatham R. L. (2009). Multivariate Data Analysis. New Jersey: Pearson Prentice Hall, USA

Heinrich A., Lis A., \& Pleines H. (2007). Factors influencing corporate governance in postsocialist companies: an analytical framework. The William Davidson Institute at the university of Michigan, USA 
Hu L., \& Bentler P.M. (1999). Cutoff criteria for fit indexes in covariance structure analysis: Conventional criteria versus new alternatives. Structural Equation Modeling: A Multidisciplinary Journal, 6(1), 1-55. https://doi.org/10.1080/10705519909540118

Hudson M., Smart A., \& Bourne M. (2001). Theory and practice in SME performance measurement systems. International Journal of Operations and Production Management, 21(8), 1096 - 1115. https://doi.org/10.1108/EUM0000000005587

Hulland J. (1999). Use of partial least squares (PLS) in strategic management research: A review of four recent. Strategic Management Journal, 20(2), 195-204. https://doi.org/10.1002/(SICI)1097-0266(199902)20:2<195::AID-SMJ13>3.0.CO;2-7

Ibrahim R., \& Primiana I. (2015). Influence Business Environment on the Organization Performance. International Journal of Scientific and Technology Research, 4(4), 283-293

James B.J. and Joseph C. (2015). Corporate Governance Mechanisms and Bank Performance: Resource-based View. Procedia Economics and Finance, 31(2015) 117-123. https://doi.org/10.1016/S2212-5671(15)01138-7

Kaymak T., \& Bektas E. (2008). East Meets West, Board Characteristics in an Emerging Market: Evidence from Turkish Banks. Corporate Governance: An International Review, 16(6), 550-561. https://doi.org/10.1111/j.1467-8683.2008.00713.x

Kennedy P. (1992). A Guide to Econometric. MIT Press, Cambridge, MA, USA

Kuznetsova N.V., Rahimova L.M., Gafurova V.M., Simakov D.B., Zinovyeva E.G., \& Ivanova L.A. (2017). External Environment as a Factor of Ensuring the Competitiveness of Organizations in the Regional Market of Medical Services. European Research Studies, 20(4A), 308-322

Lan L.L., \& Hearacleous L. (2010). Rethinking agency theory: The view from law. Academy of Management Review, 35(2), 294-314. https://doi.org/10.5465/AMR.2010.48463335

Levitt B., \& March J. G. (1988). Organisational learning. Annual Review of Sociology, 14(1), 319-338. https://doi.org/10.1146/annurev.so.14.080188.001535

Ljubojevic C., Ljubojevic G., \& Maksimovic N. (2013). Corporate Governance and Competitive Capability in Serbian Companies: Industry, Science and Policy Makers for Sustainable Future. Proceedings of the 14th International Conference, Koper- Slovenia, 101-112

Margolis J.D., \& Walsh J.P. (2003). Misery loves companies: rethinking social initiatives by business. Administrative Science Quarterly, 48(2), 268-305. https://doi.org/10.2307/3556659

Mia L., \& Clarke B. (1999). Market competition, management accounting systems and business unit performance. Management Accounting Research, 10(2), 137-158. https://doi.org/10.1006/mare.1998.0097

Miller K.D. (1993). Industry and country effects on managers' perceptions of environmental uncertainties. Journal of International Business Studies, 24(4), 693-714. https://doi.org/10.1057/palgrave.jibs.8490251 
Nicholson G., \& Kiel G. (2007). Can Directors Impact Performance? A Case Based Test of Three Theories of Corporate Governance. Corporate Governance: An International Review, 15(4), 585-608

Nicolaescu E. (2012). Business Environment and Corporate Governance in Public Entities. International Journal of Academic Research in Business and Social Sciences, 2(12), 347-352. https://doi.org/10.1111/j.1467-8683.2007.00590.x

Olsson U.H., Foss T., Troye S.V., \& Howell R.D. (2000). The Performance of ML, GLS and WLS Estimation in Structural Equation Modeling Under Conditions of Misspecification and $\begin{array}{llll}\text { Nonnormality. Structural } \quad \text { Equation } & \text { Modeling, } & \text { 7(4), }\end{array}$ https://doi.org/10.1207/S15328007SEM0704_3

Otley D.T. (1980). The contingency theory of management accounting: Achievement and prognosis. Accounting, Organisations and Society, 5(4), 413-428. https://doi.org/10.1016/0361-3682(80)90040-9

Pelham A.M. (1999). Influence of Environment, Strategy, and Market Orientation on Performance in Small Manufacturing Firms. Journal of Business Research, 45(1), 33-46. https://doi.org/10.1016/S0148-2963(98)00026-5

Pratistha B. (2016). The Influence of Strategic Control, Strategy Orientation, and Business Environment on Competitive Strategy and Its Effect to Business Performance. Academy of Strategic Management Journal, 15(1), 15-23

Scott W. R. (2001). Institutions and Organisations. Sage: Thousand Oaks, CA, USA

Shleifer A., \& Vishny R.W. (1997). A survey of corporate governance. Journal of Finance, 52(2), 737-783. https://doi.org/10.1111/j.1540-6261.1997.tb04820.x

Soltani B. (2005). Factors Affecting Corporate Governance and Audit Committees in Selected Countries. The Institute of Internal Auditors Research Foundation, USA

Spencer D.L. (2011). Testing Mediation Using Multiple Regression and Structural Equation Modelling Analyses in Secondary Data. Evaluation Review, 35(3), 240-268. https://doi.org/10.1177/0193841X11412069

Tu P.A. (2012). The impact of entrepreneurial characteristics on bribery incidence in transition economies. Asia Academy of Management Journal, 17(2), 155-175

Vo V.D. (2015). The effects of local business environments on SMEs' performance: Empirical evidence from the Mekong delta. Asian Academy of Management Journal, 20(1), $101-122$

Volberda H.W., Weerdt N., Verwaal E., Stienstra M., \& Verdu A.J. (2012). Contingency fit, institutional fit, and firm performance: A metafit approach to organisation-environment $\begin{array}{llll}\text { relationships. } & \text { Organisation } & \text { Science, } & \text { 23(4), }\end{array}$ https://doi.org/10.1287/orsc.1110.0687 


\section{Macrothink}

Asian Journal of Finance \& Accounting ISSN 1946-052X 2018, Vol. 10, No. 1

Weir C., \& Laing D. (2001). Governance structures, director independence and corporate performance in the UK. European Business Review, 13(2), 86 - 95. https://doi.org/10.1108/09555340110385254

White J. W., \& Ingrassia P. (1992). Board ousts managers at GM: Takes control of crucial Committee. The Wall Street Journal, April 7th, A1, A8

Zabri S.M., Ahmad K., \& Wah K.K. (2016) Corporate governance practices and firm performance: Evidence from top 100 public listed companies in Malaysia. Procedia Economics and Finance, 35, 287-296. https://doi.org/10.1016/S2212-5671(16)00036-8

Zucker L.G. (1987). Institutional theories of organisation. Annual Review of Sociology, 13(1), 443-464. https://doi.org/10.1146/annurev.so.13.080187.002303 